\title{
MODEL INOVASI PENGEMBANGAN KURIKULUM PAI UNTUK MENGHADAPI REVOLUSI INDUSTRI 4.0
}

\author{
Alif Achadah \\ Universitas Islam Raden Rahmat Malang \\ E-mail : achadahalif@gmail.com
}

\begin{abstract}
The current quality of education depends on graduates produced by educational institutions. And the low competitiveness of graduates from educational institutions is a problem that must be addressed immediately. The way to overcome these problems is by innovation or changes in the field of curriculum applied in educational institutions. Particularly for the PAI curriculum, innovations must also be made aimed at realizing graduates of high intelligence and morality. And to achieve graduates who are in accordance with the objectives of PAI education it is necessary to examine the models in developing the PAI curriculum. This study uses a qualitative method that collects data using observation, interviews, and documentation. It is known that the development of innovation in the curriculum needs to be done as an effort to improve the quality of education and the quality of graduates from schools in welcoming the 4.0 era.
\end{abstract}

Keywords: models, innovation, PAI curriculum, industrial revolution 4.0.0

\section{PENDAHULUAN}

Pembelajaran adalah hal yang esensi dalam masyarakat saat ini. Adanya pendidikan juga tak bisa lepas dari peran kurikulum yang sebagai sistem aturaan pada proses pembelajaran. Kurikulum pada dasarnya adalah rncangan atau sistem yang berisi tentang rancangan proses pembelajaran yang seyogyanya dapat diterapkan dalam lembaga pendidikan. Adanya kurikulum adalah suatu bentuk renungan dan pemikiran dari pakar atau tokoh pendidikan yang sudah dianggap berkompeten pada bidangnya, sehingga kurikulum dianggap adalah senjata kunci sebagai upaya peningkatan mutu pendidikan.

Dalam lembaga pendidikan, adalah sarana inti dalam penerapan kurikulum. Lebih khususnya adalah kelas (ruang pembelajaran) sebagai tempat untuk menguji kurikulum karena dalam kelas inilah seorang guru akan menerapkan metode, prinsip, tema, penilaian, yang semua itu sudah diatur dalam sebuah kurikulum. Dituntut untuk intelegensi dan ketrampilanyan yang tinggi untuk dapat menerapkan semua hal tersebut.

Kurikulum memegang peran yang esensi pada tingkatan peningkatan mutu pendidikan terlebih untuk mengetahui model-model pengembangan kurikulum PAI di tingkat SD. Karenanya sangatlah penting adanya inovasi dalam sistem pendidikan sebagai upaya untuk menjadikan peserta didik dan lulusan dari lembaga pendidikan mempunyai kompetensi yang tinggi sehingga dapat berguna bagi lingkungan sosial serta mampu menghadapi tantangan revolusi industri 4.0. 


\section{METODE}

Adapun sistem pengumpulan data pada penelitian ini dengan cara kualitatif. Adapun metode kualitatif adalah metode penelitian yang digunakan untuk mencari data secara ilmiah dan objektif, yang keberadaan peneliti bersifat inti atau pokok dalam penelitian ini. Adapun cara untuk mendapatkan data dilakukan dengan cara interview, observasi, dan dokumentasi.

Adapun asbabul nuzul tentang penggunaan metode penelitian secara kualitatif dalam penelitian ini karena metode penelitian kualitatif dipandang peneliti sebagai metode yang paling cocok untuk meneliti fenomena-fenomena yang terjadi di sekitar kita secara objektif karena dapat berinteraksi langsung dengan objek penelitian (Moleong, 2018, hal. 120).

\section{HASIL DAN PEMBAHASAN}

\section{Inovasi Kurikulum}

Kata Inovasi terdengar tidak asing bagi kita, tapi banyak dari kita sebetulnya tidak faham betul apa arti dari kata "Inovasi". Dapat diketahui bahwa dalam Bahasa Indonesia kata "Inovasi” berarti penemuan atau perubahan sesuatu yang belum pernah ada, penelitian-penelitian yang tidak sama dengan yang sudah ada (pemikiran, cara, perkakas) (RI, 1990, hal. 333). Dalam buku lain juga disebutkan bahwa inovasi pendidikan adalah bentuk dari berubahnya sesuatu menjadi sesuatu yang baru yang membawa kebaikan dari segi kualitas, perubahan tersebut seyogyanya harus berbeda dengan yang sebelumnya sehingga dapat menjadi tolok ukur dalam pencapaian capaian tertentu yang sudah direncanakan (Surayasubroto, 1990, hal. 127).

Adapun hal-hal yang menuntut adanya inovasi, yaitu:

1. Berubahnya ilmu pengetahuan dan teknologi

2. Jumlah penduduk yang semakin pesat

3. Semangat sosial dalam mencapai pendidikan yang tinggi

4. Merosotnya output lembaga sekolah

5. Sedikitnya hubungan antara lembaga formal dengan semangat sosial yang semakin meningkat

6. Kecilnya atau masyarakat belum merasakan betapa pentingnya perubahan intelektual dalam menghadapi perkembangan zaman di era revolusi industri (Hasbullah, 2015, hal. 191-193).

Inovasi pendidikan hakikatnya adalah bertujuan untuk memecahkan permasalahan dalam pendidikan sehingga dapat menghasilkan para lulusan yang dapat bersaing dengan perkembangan zaman. Secara signifikan dapat diidentifikasikan beberapa tujuan adanya inovasi pendidikan, yaitu: (Malang, hal. 201)

1. Perubahan pendidikan merupakan jawaban dari persoalan-persoalan lembaga formal yang meliputi: 

a. Tidak adilnya layanan pendidikan
b. Tidak seimbangnya pelaksanaan pembelajaran yang signifikan
c. Kurangnya manajemen waktu pengajaran
d. Membuang-buang waktu dalam materi pelajaran
e. Sedikitnya sosialisasi tentang peraturan yang berlaku
f. Menurunnya pengahargaan terhadap kultur negeri
g. Menurunnya sikap bangga dengan jati diri bangsa (Ekosusilo, hal. 93-94)

2. Perubahan pendidikan merupakan cara pengembangan yang lebih spesifik dan praktis. Inovasi atau perubahan dalam pembelajaran PAI dirasa sangat perlu karena untuk mengimbangi antara pengetahuan umum untuk kepentingan profesioanalitas dengan pengetahuan agama sebagai wujud keimanan kepada Tuhan YME. Dalam pembelajaran PAI hendaknya dan bahkan perlu untuk adanya temuan-temuan baru dalam strategi pembelajaran seperti penggunaan media teknologi Handphone untuk memanfaatkan aplikasi Google untuk mencari informasi yang dirasa dibutuhkan untuk mendukung materi pembelajaran. Dalam aplikasi google dapat ditemukan berbagai macam artikel yang terkait dengan tema tertentu yang hal tersebut akan menambah wawasan peserta didik karena dapat membaca banyak informasi dan teori-teori pendidikan walaupun tanpa membeli buku secara langsung di toko buku. Hal ini sebenarnya sangat efisien untuk dapat meningkatkan kualitas pendidikan dengan catatan media teknologi tersebut dipergunakan dengan semestinya dan dalam kapasitas yang wajar.

Penerapan teknologi bukanlah dirasa berlebihan jika dapat diterapkan dalam proses pembelajaran tentunya tetap dalam kontrol guru dan orang tua. Karena dengan penerapan meedia teknologi yang baik dalam pembelajaran PAI itu artinya pembelajaraan PAI sudah mengalami inovasi dalam pendidikan. Dengan hal tersebut diharapkan paraa lulusan sekolahsekolah Islam cakap dan cerdas dalam ilmu agama tetapi juga tidak ketinggalan dengan perkembangan teknologi sebagai upaya menghadapi perkembnagaan zaman. Sehingga pada intinya baahwa inovasi tersebut dilakukan dengan cara invention (temuan baru) atau cara discovery (penemuan) (Sanjaya, 2009, hal. 317).

Dalam kenyataannya, pergantian kurikulum saat ini adalah salah satu wujud dari inovasi yang wadahnya adalah lembaga formal yang dimaksud adalah sistemnya. Tapi yang perlu menjadi perhatian adalah kenapa kurikulum tersebut terus-menerus berganti. Pergantian tersebut karena memang murni karena pergantian kebijakan dari menteri, atau kurikulum berganti memang karena tuntutan zaman? kenyataannya yang sekarang terjadi adalah bahwa kurikulum tersebut berganti seiring dengan pergantian menteri akan tetapi ketika pergantian menteri tersebut justru hakikatnya telah terjadi inovasi dalam kurikulum. Mengapa? karena ketika menteri yang baru akan mengganti kurikulum, maka menteri tersebut telah melakukan evaluasi yang hal tersebut telah ditemukan kebaikan dan keburukan dari kurikulum yang telah 
dilaksanakan. Ketika pemerintah telah melakukan evaluasi, maka akan teridentifikasi kelemahan dan kelebihan yang ketika kelemahan harus dicari penyelesaiannya.

Fenomenanya adalah bahwa kelemahan yang timbul akan penerapan suatu kurikulum adalah bahwa sekolah yang telah memakai kurikulum tertentu para lulusannya tidak bisa bersaing dengan perkembangan zaman atau keadaan sosial yang semakin berkembang. Hal itu berarti, pergantian kurikulum karena pergantian menteri itu merupakan hal yang berbanding lurus dengan tuntutan perkembangan zaman. Ketika zaman yang semakin maju, yang sekarang sering disebut dengan zaman 4.0 harusnya dilembaga pendidikan menggunakan kurikulum yang membuat anak didik menjadi lebih aktif sehingga dapat meningkatkan daya intelektual, kreatifitas, dan ketrampilan yang semua hal tersebut berguna bagi kehidupan sosial untuk menjawab tantangan dunia kerja.

\section{Kurikulum PAI}

Menurut Caswel dalam buku karangan Nana Syaodih Sukmadinata dalam buku Pengembangan Kurikulum mengemukakan bahwa kurikulum adalah beberapa kumpulan kejadian peserta didik atas bimbingan seorang guru (to be composed of all the experience children have under the guidance of teachers) (Sukmadinata, 2002, hal. 4). Kurikulum adalah salah satu bentuk cara untuk menuju inovasi dalam lembaga formal karena kurikulum adalah aspek dalam peningkatan kualitas pendidikan. Dalam kaitannya PAI, kurikulum yang dinilai berhasil dalam lembaga resmi dan memenuhi esensi pembelajaran agama adalah kurikulum yang bermuatan menyeluruh dan menggabungkan aspek-aspek yang ada, yang meliputi pengetahuan yang diperlukan dalam mencapai kebahagiaan jasmani dan rohani dalam aktualisasi diri di masyarakat.

Adanya perubahan dalam bidang kurikulum PAI bertujuan untuk meningkatkan kepandaian murid baik dalam aspek akademik maupun keterampilan. Dalam era perkembangan zaman, peserta didik dituntut agar dapat bersaing dengan para lulusan-lulusan sekolah lain, sehingga kurikulum PAI juga disiapkan untuk memenuhi kebutuhan para siswa dalam rangka mempersiapkan persaingan dalam dunia kerja.

Upaya meningkatkan sistem pendidikan, Islam hendaknya mempunyai prinsip yang teguh agar kurikulum mempunyai kemanfaatan untuk masyarakat. Prinsip kurikulum meliputi prinsip filosofis, sosial, budaya, kejiwaan. Argumentasi tersebut hampir sama dengan tokoh yang lain yang mengemukakan bahwa prinsip kurikulum meliputi prinsip filosofi, sosial budaya, dan psikologi. Kemajuan pengetahuan teknologi adaalah untuk menyempurnakan beberapa prinsip di atas seiring dengan pengaturan yang baik (Andayani, 2004, hal. 53-56).

Berdasarkan penjelasan sebelumnya, dapat disimpulkan bahwa pembelajaran PAI bertujuan untuk mencetak lulusan yang mampu bersaing dengan perkembangan zaman. Tak hanya itu, kurikulum PAI bertujuan untuk membentuk karakter pribadi yang tangguh secara intelektual dan 
secara spriritual. Tangguh secara intelektual artinya adalah bahwa mempunyai pemahaman dan kemampuan yang tinggi akan suatu kompetensi tertentu sesuai dengan spesifikasi keilmuan yang ditekuni sebagai bahan untuk masuk kedunia kerja, sedangkan tangguh dalam spiritual adalah mempunyai kesalehan pribadi dalam megerjakan ajaran agamanya sebagai bekal untuk aktualisasi diri dalam lingkungan sosial. Spiritual ini diharapkan bisa menjadi bangunan yang kuat dalam diri individu dan dapat sebagai filter yang melindungi individu dari perilaku yang tidak sesuai dengan aturan.

\section{Pengembangan Inovasi Kurikulum PAI dalam Menghadapi Revolusi Industri 4.0}

Dalam prakteknya, pengembangan kurikulum dirasa sangat perlu keberadaannya dalam upaya meningkatkan mutu pendidikan. Setidaknya diketahui beberapa prinsip dalam pengembangan kurikulum, yaitu:

1. Prinsip Berhubungan adalah prinsip yang berarti bahwa kurikulum yang diimplementasikan atau dipakai harus mempunyai hubungan antara tujuan, isi, bahkan proses kurikulum tersebut dengan tuntutan atau kebutuhan situasi sosial yang berkembang di masyarakat

2. Prinsip Fleksibilitas adalah prinsip yang bermaksud bahwa kurikulum adalah sebuah aturan yang dipakai dalam proses pembelajaran untuk upaya mencerdaskan individu tetapi aturan tersebut memungkinkan untuk terjadinya penyesuaian-penyesuaian tergantung kondisi psikologi, sosial, budaya seorang peserta didik.

3. Prinsip Kontinuitas adalah bahwa kurikulum mempunyai prinsip berkesinambungan. Bahwa kurikulum adalah proses belajar yang terus menerus sehingga pengetahuan yang diperoleh oleh seorang anak dari SD, SMP, SMA, PT mempunyai kesinambungan yang nantinya akan menjadi kemampuan khusus yaitu keahlian yang berujung pada profesi

4. Prinsip Praktis adalah dapat dimengerti dengan mudah dilaksanakan atau efisien. Kurikulum yang baik adalah sistem pembelajaran yang bisa diterapkan baik dalam kondisi peralatan yang murah dan sederhana dengan segala keterbatasan.

5. Prinsip Efektivitas. Dalam prinsip ini mengandung pengertian bahwa keberhasilan implementasi dari kurikulum adalah dari dua aspek yaitu kuantitas dan kualitas (Sukmadinata, 2002, hal. 150-151).

Menurut al-Taony al-syaibani ada lima ciri kurikulum pendidikan agama Islam, yaitu:

1. Memperlihatkan esensi kepercayaan dan perilaku pada semua aspek yang dapat identifikasi sebagai norma agama

2. Ruang lingkup kajian yang universal

3. Adil dalam penerapan ilmu yang terkandung dalam sistem pendidikan agama dengan ilmu-ilmu umum sebagai aktualisasi di masyarakat 
4. Bersifat universal ketika mengatur materi pembelajaran yang akan disampaikan ke murid

5. Kurikulum yang dirancang harus memperhatikan faktor internal dan eksternal dari murid (Nata, 1997, hal. 127).

Dari beberapa ciri kurikulum agama di atas dapat tentang sistem pembelajarn PAI harus bersifat menyeluruh dan menonjolkan tujuan dari pembelajaran agama Islam. Dalam hal ini artinya adalah bahwa PAI bukan hanya terletak pada penyelesaian atau penyampaian materi saja, tapi lebih terletak pada implementasi dari teori dalam pembelajaran agama tersebut pada kehidupan sehari-hari. Karena jika materi itu hanya disampaikan tapi tidak dilakukan atau diimplimentasikan pada lingkungan sosial, itu artinya penerapan kurikulum pembelajaran PAI tidak berhasil dilaksanakan. Adapun yang berkaitan dengan faktor yang mempengaruhi pengembangan kurikulum yaitu:

1. Universitas

2. Lingkungan sosial

3. Norma atau aturan (Sukmadinata, 2002, hal. 158-159).

Adapun model-model pengembangan kurikulum yaitu:

1. Model administrasi

2. Model akar rumput

3. Model Beauchamp's

4. Model demonstrasi

5. Model terbalik

6. Model Roger's relasi individu

7. Model sistem penelitian tindakan

8. Model kemunculan tindakan (Sukmadinata, 2002, hal. 161-170).

Di makalah ini akan lebih khusus membahas tentang model-model pembelajaran PAI di tingkat SD dalam upaya menghadapi revolusi industri 4.0. sebenarnya terlebih dahulu perlu dimengerti tentang perubahan industri. Konsep revolusi industri 4.0 ini adalah wacana yang dikemuakakan oleh Prof. Klaus Schwab. Beliau adalah ahli ekonomi yang berasal dari Jerman dan pencetus "Forum Ekonomi Dunia (WEF)" tercantum dalam literatur The Fourth Industrial Revolution, menyebutkan tentang perubahan perubahan industri 4.0 hakikatnya adalah bisa merubah aturan kehidupan, serta interaksi antar individu.

Dengan adanya sejarah dari penerapan revolusi industri di atas maka dapat kita mengerti bahwa keberadaan revolusi industri tersebut sangat penting dalam aktualisasi penerapan pendidikan. Terkait dengan PAI di Sekolah Dasar, maka harus benar-benar diperhatikan karena sekolah dasar adalah salah satu pendidikan awal dalam lembaga pendidikan. Setidaknya ketika di tingkat sekolah dasar para peserta didik mengerti dan mampu mengamakan pendidikan agama 
Islam yang telah didapatnya dari sekolah. Sekurangnya ada beberapa hal yang harus diinovasi dari murid dalam segi pendidikan:

1. Yang paling inti adalah perubahan cara berfikir anak bangsa sekarang

2. Pentingnya tugas lembaga pendidikan dalam mengidentifikasi dan menyalurkan faktor eksternal yang ada dalam anak banagsa.

3. Mengasah dan menginterpretasi intelegensi akademik sebagai upaya dalam mewujudkan lulusan yang dapat menjawab dan mengambil peluang perkembangan teknologi.

Sebagai upaya menjawab tantangan perubahan zaman 4.0, pendidikan seyogyanya dapat mencetak anak bangsa yang produktif, imajinatif, inventif. Wacana tersebut merupakan hal yang harus diwujudkan dengan memaksimakan kecanggihan teknologi sebagai sarana pembelajaran yang seyogyanya dapat menciptakan lulusan yang mebawa manfaat bagi perubahan zaman. Dan bangsa kitapun harus meningkatkan mutu alumni dari sekolah sehingga dapat bersaing pada zaman modern sebagai tenaga profesional.

Dalam relevansinya pembelajaran PAI dalam tingkat SD untuk menghadapai revolusi industri 4.0 adalah pembelajaran PAI harus lebih menyenangkan, kreatif, dan inovatif, serta mampu mengahsilkan lulusan yang kompetitif. Pembelajaran PAI bertujuan untuk membentuk peserta didik yang tidak hanya pandai dalam intelegensi umum, tapi juga peserta didik yang mempunyai akhlak yang bagus. Untuk dapat bersaing dengan revolusi industri 4.0 maka para lulusan dari sekolah dasar harus mampu memahami intelektual materi secara akdemis dan berperilaku yang baik tentunya sesuai dengan ajaran agama Islam.

Telah tiba waktunya melepaskan sistem yang biasanya mengedepankan pembelajaran yang monoton atau hanya ceramah. Cara belajar kita harus mulai dirubah menjadi pembelajaran yang menarik sehingga lebih menjadikan peserta didik lebih aktif. Sikap tersebut sangat dibutuhkan dalam menghadapi arus perubahan IPTEK. Dalam sebuah literatur disebutkan bahwa ciri pendidikan tahun 2100-an bercirikan kreatif, berfikir kritis, komunikatif, dan kolaborasi.

Manfaat blended learning, 1 lebih efektif daripada hanya belajar tatap muka atau hanya belajar secara online. Blended learning 2 dapat meningkatkan hasil belajar, Blended learning 3 dapat menjadi cara yang tepat untuk memperpanjang waktu belajar sehingga mahasiswa dapat mencapai standar kesiapan di perguruan tinggi dan dunia kerja. Blended learning dapat memungkinkan mahasiswa memperoleh literasi digital dan keterampilan belajar online. Blended learning dapat dijadikan cara yang tepat untuk menutupi pembelajaran yang tidak dapat dihadiri secara tatap muka. Blended learning dapat membuat tugas menjadi lebih menarik dan fleksibel. Blended learning dapat memungkinkan untuk dilakukan pemantauan kemajuan mahasiswa secara lebih mudah.

Aturan pembelajaran memerlukan pembaruan sebagai upaya menjawab tantangan perkembangan zaman. Salah satu upaya pemerintah dalam menjawab tantang tersebut adalah 
dengan budaya membaca dan memperkuat kemampuan menulis yang bertujuan pada kemampuan menulis online, kemampuan menulis teknologi, dan kemampuan menulis sosial.

\section{Implementasi Inovasi Kurikulum PAI di Sekolah Dasar dalam Menghadapi Revolusi Industri 4.0}

Dalam pendidikan sekolah dasar atau SD, peserta didik sangatlah dituntut untuk dapat bersikap mandiri, kreatif, dan cerdas. Dalam penerapan kurikulum 2013, para siswa mempunyai andil yang sangat penting dalam keberhasilaan program belajar mengajar. Dalam hubungannya dengan implementasi inovasi kurikulum PAI dalam Sekolah Dasar, adalah yang terpenting bahwa penerapan ajaran dan akhlak peserta didik setelah mendapatkan materi agama. Indonesia bukanlah negara Islam tetapi Indonesia adalah negara yang hampir $90 \%$ warganya beragama Islam. Banda-Aceh adalah satu-satunya propinsi di Indonesia yang menerapkan hukum Islam dalam pemerintahannya. Dan tak lupa tetap menerapkan perilaku saling menghormati antar pemeluk agama lain seperti yang tertera pada pancasila sila ke-3, sehingga tidak akan terjadi konflik karena permusuhan dalam perbedaan agama.

Dalam bidang pendidikan, pemerintah Banda-Aceh telah menerapkan kurikulum Islam untuk setiap tingkat pendidikan. Penerapan ini bertujuan untuk memperkuat generasi muda dan anak-anak Aceh dalam memahami pengertahuan agama (Marzuki, 2016). Adapun penerapan pendidikan agama Islam diperuntukkan untuk memperkuat etika dan perilaku dari peserta didik dengan cara membuat program Diniyyah. Program Diniyyah adalah program pembelajaran pendidikan agama Islam yang diadakan $2 x$ dalam seminggu yang diterpkan dalam sekolah umum. Sekolah umum yang menerapkan program Diniyyah 2x seminggu adapun pembelajarannya dimulai dari pukul 14.00-16.00, sedangkan sekolah yang menerapkan program Diniyyah sekali dalam seminggu dimulai pukul 13.00-17.30 dalam setiap pertemuannya. (Marzuki, 2016, hal. 20). Dengan adanya penerapan program Diniyyah tersebut, dirasa cenderung efektif dalam pembentukan karakter religius siswa. Dan dengan adanya program Diniyyah tersebut akan memastikan semua siswa memahami pengetahuan Islam karena dibentuk dalam format formal yang dikemas semenarik mungkin bagi siswa sehingga mau untuk belajar pengetahuan agama Islam.

Adapun sistem implementasi kurikulum Islam (penerapan program Diniyyah) dengan model Diniyyah dapat menjadi salah satu model implementasi kurikulum Islam bagi lembaga pendidikan lain dan di luar provinsi Banda-Aceh. Hal lain yang dapat menjadi pertimbangan dalam implementasi inovasi kurikulum PAI dalam menghadapi revolasi industri 4.0 adalah penerapan teknologi. Dalam Association for Educational Communication and Technology (AECT) pada tahun 1986 mengemukakan bahwa teknologi pendidikan merupakan proses kompleks dan terpadu yang melibatkan orang, prosedur, gagasan, peralatan, dan organisasi untuk menganalisis 
masalah, mencari jalan pemecahan, melaksanakan, mengevaluasi dan mengelola pemecahan masalah yang menyangkut semua aspek belajar manusia (Muslimin, 2017, hal. 23-24). Dengan adanya penerapan teknologi dalam pembelajaran PAI diharapkan bahwa output yang dihasilkan akan lebih baik. Artinya bahwa guru akan lebih sering dan cenderung memanfaatkan alat-alat ataupun produk (media) teknologi yang mereka anggap dapat membantu dalam proses pembelajaran sehingga perlu menjadi perhatian bagi para pengembang teknologi pembelajaran (Syahri, 2018, hal. 62-80). Dengan pemanfaatan alat-alat tersebut dapat diartikan bahwa alat-alat tersebut memanfaatkan media yang cenderung memanfaatkan teknologi sebagai upaya peningkatan pembelajaran yang lebih maju dan lebih menarik, sehingga pembelajaran sekarang cenderung bersifat tidak sebanyak materi apa yang disampaikan ke murid, tapi dengan teknik atau cara apa sehingga materi dan pesan pembelajaran tersebut bisa sampai ke murid.

Diharapkan dengan pemanfaata teknologi akan berupa alat-alat pembelajaran yang cenderung modern dan canggih, akan mempermudah dalam mentransfer ilmu pengetahuan yang dalam hal ini adalah ilmu pendidikan agama Islam. Islam sebagai agama Rahmatan Lil 'Alamin (religius) seharusnya dapat mencetak lulusan atau peserta didika yang berakhlakul karimah tetapi pada kenyataanya banyak dari murid atau lulusan sekolah Islam kurang dapat berfikir kritis dan kurangnya dapat bersaing dengan perkembangan zaman dan tidak cakap dalam penggunaan teknologi. Oleh karena itu, untuk mengahadapi revolusi industri 4.0 para murid harus disiapkan terutama dalam akhlak dan perilaku yang baik dan intelegensi yang maksima pula, sehingga peluang-peluang yang timbul akan hadirnya revolusi industri 4.0 dapat diambil oleh penerus kita lebih khusunya generasi Islami. Peluang-peluang dalam revolusi industri 4.0 bukan hanya milik lulusan sekolah umum saja, tapi sekolah Islam juga harus ambil peran seperti mendapat pekerjaan di lembaga yang maju, modern, dan bonafit, dan dapat sebagai tenaga profesional. Islam harus menjadi tonggak dan berdeiri tegak di tengah-tengah perkembangan dunia yang semakin maju, sehingga akhlakul karimah sangat penting keberadaannya dalam dunia sosial.

\section{KESIMPULAN}

Adanya perubahan dalam diri individu seharusnya dapat merubah pula perilaku yang ada dalam individu. Perubahan peradaban, perkembangan zaman, perubahan teknologi juga harus menjadikan individu dan seseorang menjadi lebih baik. Ketika sudah mendapatkan pendidikan, maka individu tersebut harus diidentifikasi menjadi pribadi yang sempurna. Revolusi industri adalah salah satu era ketika semua hal menjadi lebih canggih dan lebih maju sehingga peserta didik, dan lulusan dari lembaga pendidikan harus dapat menjawab tantang tersebut dan menangkap peluang intelektual yang ada dengan pemanfaatan teknologi yang ada. 


\section{ACKNOWLEDGEMENT}

Adapun artikel ini adalah untuk mengetahui sejauh mana penerapan dari inovasi yang ada di suatu lembaga pendidikan atau sekolah dalam upaya untuk meningkatkan pembelajaran yang dilaksanakan. Adanya inovasi dalam sekolah dirasa sangat penting dalam rangka untuk meningkatkan mutu pendidikan dalam menyongsong era 4.0. Keterlibatan lembaga pendidikan dalam artikel ini juga sangat membantu sebagai sarana pendukung terlaksananya penerapan inovasi dalam sekolah.

\section{BIBLIOGRAFI}

Majid, Abdul. (2012). Belajar dan Pembelajaran Pendidikan Agama Islam. Bandung: Remaja Rosdakarya.

Gintings, Abdurakhman. (2008). Esensi Praktis Belajar dan Pembelajaran. Humaniora.

Amir. T. M. (2009). Inovasi pendidikan Melalui Problem Based Learning Bagaimana pendidik Memberdayakan Pembelajar di Era Pengetahuan. Bandung: Kencana.

Jaskati, Eti. (2015). Dasar-Dasar Model Pembelajaran. Departemen Pendidikan Nasional.

J.J. Hasibuan \& Moedjiono. (1986). Proses Belajar Mengajar. Remadja Karya.

Dahlan, M. D. (1990). Model-Model Mengajar, Beberapa Alternatif Interaksi Beiajar Mengajar. Jogjakarta : Diponegoro.

Marzuki. Diniyyah In Public School: A Model Of IslamicCurriculum Implementation Multi Religious Society In Banda Aceh Indonesia. The Journal Of Social Science. Jurna Ilmiah Peuradeun. Vol: 4 No.1 Januari 2016.

Muhaimin. (2004). Paradigma Pendidikan Islam. Bandung: Remaja Rosdakarya.

Hamalik, Oemar. (2011). Kurikulum Dan Pembelajaran. Bandung: Bumi Aksara.

Trianto. (2012). Mendesain Model Pembelajaran Inovatif-Progresif: Konsep, Landasan, dan Implementasinya pada Kurikulum Tingkat Satuan Pendidikan. Bandung: Kencana Predana Media Group.

Sukmadinata, Nana Syaodih. (2017). Pengembangan Kurikulum: Teori dan Praktek. Bandung : PT. Remaja Rosdakarya 